\title{
Assessing community child passenger safety efforts in three Northwest Tribes
}

\author{
M L Smith, L R Berger
}

Injury Prevention 2002;8:289-292

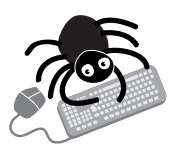

An appendix to this paper can be found on http:// www.injuryprevention.com/

See end of article for authors' affiliations

................

Correspondence and reprint requests to: $\mathrm{Dr}$ Lawrence Berger, 1335

Bryn Mawr Drive NE, Albuquerque, NM 87106-1101, USA; bergerlaw@msn.com

\begin{abstract}
Objective: To identify strengths and weaknesses in community based child passenger safety programs by developing a scoring instrument and conducting observations of child restraint use in three Native American communities.

Setting: The three communities are autonomous Tribal reservations in the Pacific Northwest. Their per capita incomes and rates of unemployment are comparable.

Methods: In each community, 100 children under 5 years old were observed for car seat use. A six item community assessment tool (100 points maximum) awarded points for such items as the type (primary or secondary) and enforcement of child restraint laws; availability of car seats from distribution programs; extent of educational programs; and access to data on vehicle injuries.

Results: For children from birth to 4 years, the car seat use rate ranged from $12 \%-21 \%$. Rates for infants $(71 \%-80 \%)$ far exceeded rates for $1-4$ year old children $(5 \%-14 \%)$. Community scores ranged from 0 to 31.5 points. There was no correlation between scores and observed car seat use. One reason was the total lack of enforcement of restraint laws.

Conclusions: A community assessment tool can highlight weaknesses in child passenger efforts. Linking such a tool with an objective measure of impact can be applied to other injury problems, such as fire safety or domestic violence. The very process of creating and implementing a community assessment can enhance agency collaboration and publicize evidence based "best practices" for injury prevention. Further study is needed to address methodologic issues and to examine crash and medical data in relation to community child passenger safety scores.
\end{abstract}

$\mathrm{F}$ or Native American children and youth, death rates from motor vehicle crashes are two to three times the national average. ${ }^{1}$ Most Tribes have instituted child passenger safety programs. Yet injury prevention efforts vary widely among the more than 550 federally recognized Tribes in the United States, each a sovereign nation with unique cultural, demographic, geographic, and socioeconomic characteristics. ${ }^{2}$

To assist Tribes in strengthening their child passenger safety programs, we devised an assessment process that used an objective measure of impact (observed car seat usage) and an assessment instrument to score six components of a community child passenger safety program. Selected indicators and scoring systems have been used to rank states on several injury related dimensions, such as rates of child deaths and teen deaths from injuries, ${ }^{3}$ the extent of gun control measures, ${ }^{4}$ and the strength of child passenger safety laws. ${ }^{5}$ This is the first, published exploratory study to devise a community based scoring system for child occupant protection and compare the scores to observed child restraint usage rates.

\section{METHODS}

\section{Observations of car seat use}

One hundred child passengers were observed at each reservation. Observations were conducted at intersections with a stop sign or stoplight and a speed limit of 25 miles per hour. To ensure that most vehicle occupants were Tribal members, the intersections were near Tribal headquarters, Indian Health Service (IHS) clinics, or Tribal grocery stores. Only vehicles transporting children under 5 years of age were included. One of us (MS) conducted all the observations over a one month period. Children were assigned to either infant (under 1 year) or toddler ( $1-4$ years) categories based on their size, appearance, and behavior. By using a single observer, we avoided the potential for interobserver differences in age category assignments. "Car seat usage" was defined by whether or not the child was sitting in a car seat. Elements of correct car seat usage, such as rear compared with forward facing position, were not assessed.

\section{Community child passenger safety assessment tool}

The components of our scoring instrument were based on published "best practices" and evidence based literature reviews. ${ }^{6-14}$ The six scored components were:

(1) Does the Tribe have a child restraint law?

(2) Is there vigorous enforcement of the law? How many citations were issued? Are there enforcement campaigns?

(3) Is there a comprehensive car seat distribution program? Is a certified car seat technician involved? What is the ratio of rental car seats available per child population? Are there hands-on demonstrations for parents?

(4) Are there community education programs? Are there car seat clinics? Is a National Highway Traffic Safety Administration (NHTSA) certified technician involved? Is there a vehicle safety curriculum for local Head Starts? Are there media campaigns?

(5) Is there a child passenger safety group with regularly scheduled meetings?

(6) Do Tribal staff report access to data regarding child vehicle fatalities and hospitalizations?

In assigning points to the various elements, we gave greater weight to the most effective approaches. For example, a community with a primary seat belt law received 20 points, a secondary law only 10 points. The maximum score a community could receive for its child passenger safety efforts was 100 points. We completed the child passenger safety assessment by

Abbreviations: IHS, Indian Health Service; NHTSA, National Highway Traffic Safety Administration 
Table 1 Observed child car seat use rates (\%)

\begin{tabular}{|c|c|c|c|c|}
\hline & $\begin{array}{l}\text { Reservation A } \\
(n=100)\end{array}$ & $\begin{array}{l}\text { Reservation B } \\
(n=100)\end{array}$ & $\begin{array}{l}\text { Reservation C } \\
(\mathrm{n}=100)\end{array}$ & $\begin{array}{l}\text { US rates } \\
(2000)^{16}\end{array}$ \\
\hline Overall car seat use (birth to 4 years of age) & 21 & 18 & 12 & 91 \\
\hline Car seat use for infants (less than 1 year of age) & 80 & 80 & 71 & 95 \\
\hline Car seat use rate for toddlers ( $1-4$ years of age) & 14 & 14 & 5 & 91 \\
\hline
\end{tabular}

Table 2 Child passenger safety (CPS) assessment scores by community

\begin{tabular}{|c|c|c|c|c|c|c|c|}
\hline Reservation & $\begin{array}{l}\text { Child } \\
\text { restraint } \\
\text { law (max } \\
20 \text { ) }\end{array}$ & $\begin{array}{l}\text { Enforce CPS } \\
\text { law (max } \\
20)\end{array}$ & $\begin{array}{l}\text { Car seat } \\
\text { loaner } \\
\text { program } \\
(\max 25)\end{array}$ & $\begin{array}{l}\text { Community } \\
\text { education } \\
\text { programs } \\
\text { (max 15) }\end{array}$ & $\begin{array}{l}\text { Community } \\
\text { or agency } \\
\text { CPS group } \\
\text { (max 10) }\end{array}$ & $\begin{array}{l}\text { Access to } \\
\text { data (max } \\
\text { 10) }\end{array}$ & $\begin{array}{l}\text { Total score } \\
\text { (max 100) }\end{array}$ \\
\hline A & 10 & 0 & 10 & 0 & 0 & 0 & 20 \\
\hline B & 0 & 0 & 0 & 0 & 0 & 0 & 0 \\
\hline C & 20 & 0 & 10 & 1.5 & 0 & 0 & 31.5 \\
\hline
\end{tabular}

\begin{tabular}{|llllll}
\hline \multicolumn{2}{l}{$\begin{array}{l}\text { Table } 3 \\
\text { community }\end{array}$} & Details of selected child passenger safety assessment components by \\
\hline Reservation & $\begin{array}{l}\text { Tribal child restraint } \\
\text { law }\end{array}$ & $\begin{array}{l}\text { No of tickets } \\
\text { written }\end{array}$ & $\begin{array}{l}\text { No of loaner } \\
\text { car seats } \\
\text { available }\end{array}$ & $\begin{array}{l}\text { Population of } \\
\text { children } \\
\text { (birth to } 4 \\
\text { years) }\end{array}$ & $\begin{array}{l}\text { Ratio of loaner } \\
\text { car seats to } \\
\text { child } \\
\text { population (\%) }\end{array}$ \\
\hline A & $\begin{array}{l}\text { Secondary } \\
\text { enforcement }\end{array}$ & 0 & 25 & 296 & 8 \\
B & $\begin{array}{l}\text { None } \\
\text { C }\end{array}$ & 0 & 0 & 716 & 0 \\
\hline
\end{tabular}

interviewing a variety of informants at the different reservations: public health nurses, community health representatives, IHS Service Unit Directors, Tribal health educators, Tribal police chiefs, police data entry personnel, Tribal safety officers, Head Start directors and staff, community patient advocates, contract health personnel, child safety seat program managers, and Tribal health directors. The population of children birth to 4 years of age in each community was based on the Resource Patient Management System, a computerized database of Tribal members receiving services at IHS facilities. ${ }^{15}$

The complete assessment tool is available as an appendix on the Injury Prevention web site (www.injuryprevention.com).

\section{RESULTS}

The overall use rates for child safety seats were $21 \%, 18 \%$, and $12 \%$ at the three reservations (table 1 ). Car seat use rates for infants $(71 \%$ to $80 \%)$ were much higher than for toddlers $(5 \%$ to $14 \%$ ). By comparison, restraint use rates from the National Occupant Protection Use Survey (NOPUS) conducted in the year 2000 were $95 \%$ for infants, $9 \%$ for toddlers, and $91 \%$ overall. ${ }^{16}$

Scores for the six components of the child passenger safety community assessment tool were 20,0 , and 31.5 points, out of a possible 100 (table 2). None of the reservations reported access to motor vehicle child injury or mortality data, had a community or agency group dedicated to child passenger safety issues, or had issued any citations to motorists for violation of a child restraint law (table 3 ). The reservation with the highest score had a Tribal child restraint law with primary enforcement (motorists could be stopped and cited for child passenger violations), had the car seat distribution program with the highest proportion of available car seats to child population ( $11 \%)$, and had conducted a community education activity during the previous year (child safety seat information was provided at the local Tribal health fair).

There was no correlation between a community's score on the child passenger safety assessment tool and its observed overall car seat use rate. Reservation $\mathrm{C}$ had the highest overall score (31.5), but the lowest overall car seat use rate (12\%). Reservation B, with an overall score of 0 , had an overall car seat use rate of $18 \%$ (tables 1 and 2 ).

\section{DISCUSSION}

Our study sought to bridge the gap between efficacy research and community practice. A scoring system helps to identify strengths and weaknesses in community based prevention activities. The data can be used to promote the passage and enforcement of car restraint laws, obtain Tribal and external funding for child passenger safety initiatives, and stimulate increased community involvement. ${ }^{17}$ A scoring system also allows comparisons among communities, providing a stimulus to action and promoting the exchange of information about specific strategies. Furthermore, the observational surveys provide baseline data to evaluate specific community interventions and trends over time.

That the highest score for any of the reservations' child passenger safety efforts was 31.5 points (out of a possible 100) was surprising, since motor vehicle safety has been a priority injury prevention issue for Tribes and the IHS for many years. ${ }^{2}{ }^{18}$ Equally surprising was the lack of impact of restraint laws on overall car seat use. The absence of enforcement efforts (not issuing any citations for violators and not conducting any occupant protection blitz campaigns) and the paucity of community education activities are the most likely reasons for the ineffectiveness of the restraint laws. 
The assessment tool identified numerous opportunities for improving child passenger protection at the three reservations, from increasing the number of available loaner seats to passing stronger child restraint laws. IHS injury prevention specialists are available to assist Tribes in obtaining and analyzing data. Courses on injury prevention are offered annually by the IHS Injury Prevention Program..$^{18}$ Many Tribal members receive child passenger safety training through the NHTSA which offers child occupant protection workshops and certification programs. ${ }^{19}$

Successful community injury prevention programs use multiple simultaneous strategies ("persuade, require, automatically protect"), involve community stakeholders, and employ objective measures to assess their progress. ${ }^{90}{ }^{10-24}$ Our assessment tool captures elements from each of these dimensions. However, the assessment instrument requires modifications before it is used in other settings. For example, in communities where vigorous enforcement of child restraint laws has been practiced for many years, fewer citations per population, rather than more, would be a positive indicator. Wide economic disparities among communities would make comparison of car seat availability (as expressed by the ratio of loaner car seats to total child population) problematic. All three communities in our study were economically disadvantaged (per capita income ranged from $\$ 4600$ to $\$ 6100$ per year, unemployment rates from $26 \%$ to $29 \%){ }^{25}$ Absolute measures, rather than relative ones, are needed if the instrument is to be used by individual communities to assess their own occupant protection efforts. Two of our measures, car seat availability and police citations, were scored on a relative basis (for example, the community with the highest number of child car seats available for rent or loan per 100 children $0-4$ years of age received 10 points; the community with the lowest ratio received no points). Refinements in scoring are also required for communities with multiple car seat distribution programs or several police jurisdictions. Communities may want to expand the number of items in the scoring system to include drunk-driving laws, enforcement of speed limits, or the quality of emergency medical services for children. In addition to improving the scoring system, further studies are needed to collect expanded observational data (for example, vehicle types and all vehicle occupants) and to link community scores to crash data and medical outcomes.

We envision the community assessment process being applied to other injury arenas, such as fire safety, child abuse, and minors' access to alcohol. The process consists of three steps:

(1) Establish an objective impact measure, such as observed car seat use.

(2) Devise a scoring instrument based on "best practices".

(3) Link the two measures to determine how well efforts are succeeding and where gaps exist in community interventions.

The measures of impact must be relatively easy to obtain by community members without formal evaluation training or much financial support. ${ }^{11}{ }^{17}$ Observations of car seat misuse, for example, require much more expertise than simply noting whether a child is seated in a car seat. ${ }^{26}{ }^{27}$ "Best practices" can be identified through discussions with experts, internet resources (such as the Harborview Injury Center's database and the NHTSA web site), and publications, including the reports of the Task Force on Community Preventive Services and other evidence based summaries. ${ }^{198-34}$

\section{ACKNOWLEDGEMENTS}

We are very grateful to all the community members who provided information and data; to Roger Gollub, MD, for help with the analysis; and to Karin Knopp, Service Unit Sanitarian, Bremerton, Washington, for her assistance in the design and implementation of this work.

\section{Key points}

- The most successful community injury prevention programs use multiple strategies of education, enforcement, and environmental modifications.

- A scoring system to assess community child passenger safety efforts can highlight gaps in programs and facilitate community action.

- Linking community scores to observed car seat usage rates provides a method to evaluate the impact of specific community interventions.

- Establishing an objective measure of impact, and linking it to a scoring instrument based on "best practices", is a model that can be applied to both intentional and unintentional injuries.

Authors' affiliations

M L Smith, Spokane District Office, Portland Area Indian Health Service, Spokane, Washington

L R Berger, University of New Mexico, Albuquerque, New Mexico

\section{REFERENCES}

1 Wallace LJD. Injuries among American Indian and Alaska Native children, 1985-1996. Atlanta, GA: CDC, National Center for Injury Prevention and Control, April 2000

2 Committee on Native American Child Health and Committee on Injury and Poison Prevention. The prevention of unintentional injury among American Indian and Alaska Native children: a subject review. Pediatrics 1999; 104:1397-9.

3 Annie E Casey Foundation. 1999 Kids count data book: state profiles of child well-being. Baltimore, MD: Annie E Casey Foundation, 2000.

4 Open Society Institute. Gun control in the United States: a comparative survey of state firearm laws. New York, NY: Open Society Institute, 2000.

5 National Safe Kids Campaign. Rating child passenger safety laws (www.safekids.org).

6 Grossman DC, Garcia CG. Effectiveness of health promotion programs to increase motor vehicle occupant restraint use among young children. Am J Prev Med 1999;16:12-22.

7 Task Force on Community Preventive Services. Motor-vehicle occupant injury: strategies for increasing use of child safety seats, increasing use of safety belts, and reducing alcohol-impaired driving MMWR Morb Mortal Wkly Rep 2001;50(RRO7): 1-13 (May 18).

8 Sewell CM, Hull HF, Fenner J, et al. Child restraint law effects on motor vehicle accident fatalities and injuries; the New Mexico experience. Pediatrics 1986;78: 1079-84.

9 Pless IB, Stulginskas J, Zvagulis I. Observed effects of media campaigns on restraint use. Can J Public Health 1986;77:28-31.

10 Deal LW, Gomby DS, Zippiroli L, et al. Unintentional injuries in childhood: analysis and recommendations. The Future of Children 2000;10:4-22

11 Dannenberg AL, Fowler CJ. Evaluation of interventions to prevent injuries: an overview. Inj Prev 1998;4:141-7.

12 Bolen JR, Sleet DA, Johnson VR, eds. Prevention of motor vehicle-related injuries: a compendium of articles from the MMWR, 1985-1996. Atlanta, GA: National Center for Injury Prevention and Control, 1997.

13 AAP Committee on Injury and Poison Prevention. Safe transportation of newborns at hospital discharge. Pediatrics 1999;104:986-7.

14 Rivara FP, Thompson DC, Cummings P. Effectiveness of primary and secondary enforced seat belt laws. Am J Prev Med 1999;16:30-9.

15 Resource and Patient Management System (RPMS). Site managers' cookbook, version 1.0. Billings, MT: Billings Area Indian Health Service, 1993.

16 National Highway Traffic Safety Administration. National Occupant Protection Use Survey - 2000 controlled intersection study. Research note, DOT HS 809318 . Washington, DC: National Center for Statistics and Analysis, August 2001.

17 Pless IB. Restraining children: a battle not yet won. Inj Prev 1998;4:85.

18 Smith RJ, Dellapenna AJ, Berger LR. Training injury control practitioners: the Indian Health Service model. The Future of Children 2000;10: 175-88.

19 National Highway Traffic Safety Administration home page (www.nhtsa.dot.gov).

20 Christoffel T, Gallagher SS. Injury prevention and public health: practical knowledge, skills, and strategies. Gaithersburg, MD: Aspen Publishers, 1999.

21 Institute of Medicine Committee on Trauma Research. Injury in America: a continuing public health problem. Washington, DC: National Academy Press, 1985.

22 Klassen TP, MacKay JM, Moher D, et al. Community-based injury prevention intervention. The Future of Children 2000;10:83-110. 
23 Dowswell T, Towner EM Simpson G, et al. Preventing childhood unintentional injuries - what works? A literature review. Inj Prev 1996;2:140-9.

24 Berger LR, Mohan D. Injury control: a global view. New Delhi: Oxford University Press, 1996.

25 Velarde-Tiller VE. Tiller's guide to Indian country: economic profiles of American Indian reservations. Albuquerque, NM: BowArrow Publishing Company, 1996

26 Decina LE and Knoebel KY. Child safety seat misuse patterns in four states. Accid Anal Prev 1997:29:125-32.

27 National Safe Kids Campaign. Child passengers at risk in America: a national study of car seat misuse. Washington, DC: National Safe Kids Campaign, 1999

28 Harborview Injury Prevention Research Center. Systematic reviews of childhood injury prevention interventions (http://

depts.washington.edu/hiprc/childinjury).
29 Thornton TN, Craft CA, Dahlberg LL, et al. Best practices of youth violence prevention. A sourcebook for community action. Atlanta, GA: CDC, Division of Violence Prevention, September 2000.

30 Larner MB, Stevenson CS, Behrman RE. Protecting children from abuse and neglect: analysis and recommendations. The Future of Children 1998:8:4-22.

31 Stewart K. Strategies to reduce underage alcohol use: typology and brief overview. Washington, DC: Office of Juvenile Justice and Delinquency Prevention, US Department of Justice, 1999.

32 Joint Together. How communities can strengthen their strategies to fight drug abuse using research from the National Institute on Drug Abuse (NIDA). Boston: Joint Together, 2000.

33 Anonymous. Injury-control recommendations: bicycle helmets. MMWR Morb Mortal Wkly Rep 1995;44(RR-1): 1-18.

34 Widome MD, ed. Injury prevention and control for children and youth. 3rd Ed. Elk Grove Village, IL: American Academy of Pediatrics, 1997.

\section{Music and dangerous driving}

ight About Now, The Funk Soul Brother, Check It Out Now, The Funk Soul Brother..." Fatboy Slim is OK if you're dancing, but a word of warning if you're driving: an Israeli researcher says drivers who listen to fast music in their cars may have more than twice as many accidents as those listening to slower tracks. While previous studies have shown a link between loud music and dangerous driving Warren Brodsky at Ben-Gurion University in Beer-Sheva, wondered if tempo had any effect on driver behaviour. To find out, he put a group of 28 students through their paces on a driving simulator as he exposed them to different pieces of music. Brodsky's selection included everything from laidback George Benson ballads to ultrafast clubbing anthems, and his results, he believes, have "got to be taken seriously..." (http://www.newscientist.com/news/news.jsp?id=ns99992032)

Top 10 foods that trigger car crashes. Food related wrecks prompt study on snack driving-if you eat, don't drive

Chocolate, doughnuts, and fried chicken are among the top 10 most dangerous foods to consume while driving, according to research by an insurance company trying to cut losses from food related accidents. For instance, chocolate smears everything a driver touches. The instinctive reaction is to clean it off immediately, stealing attention from the road. Then—bang—food related wreck.

Hagerty Classic Insurance, a classic car insurer based in Michigan, became interested in food related wrecks last year after a damage claim. "When we looked into it, we found that the guy's licence was restricted to having no food within reach while driving", company president McKeel Hagerty said. The man had had a number of food related wrecks. That, plus claims for food damage to interiors of collectible cars, prompted Mr Hagerty to "dig deeper". It's more the spilling than the eating, according to the research. Mr Hagerty's claims showed that most food accidents happen in the morning. Drivers en route to work are worried about wearing food stained clothes all day, so they urgently try to clean spills but crash instead, Mr Hagerty surmises. Hot coffee is infamously dangerous. It is the worst offender on the company's list-especially without a lid.

Mr Hagerty says data came from the National Highway Traffic Safety Administration (NHTSA), the Network of Employers for Traffic Safety, and company claims' files. Researchers tried to judge how hard it is to consume each food with one hand while driving, and to gauge how urgently a driver would react to a spill. Mr Michael Goodman, chief of driver behaviour research at NHTSA, said "we know that eating is a big problem" but be careful about branding it the new villain. "It's a lot easier for an investigating officer to identify food as a cause because the evidence is everywhere", he said. In the case of cell phones and other distractions, experts say there is often no evidence.

Fast food merchants are on the case. More drive through foods are packaged to fit cup holders. And products have been changed to improve what Taco Bell spokesman Laurie Gannon calls "portability". Her chain has adopted "thicker shredded cheese, crunchier taco shells, improved packaging".

Avoid these-top 10 foods that are "dangerous":

1. Coffee

2. Hot soup

3. Tacos

4. Spicy hot food

5. Hamburgers

6. Barbecued snacks

7. Fried chicken

8. Jelly doughnuts

9. Soft drinks

10. Chocolate

(From The Strait Times Interactive, May 2002) 